\title{
Correction to: Real-World Recurrence Rates and Economic Burden in Patients with Resected Early-Stage Melanoma
}

\author{
Sekwon Jang • Tayla Poretta • Tarun Bhagnani • Qing Harshaw • \\ Matthew Burke · Sumati Rao
}

Published online: July 18, 2020

(C) The Author(s) 2020

Correction to: Dermatol Ther (Heidelb) https://doi.org/10. 1007/s13555-020-00404-9

The presentation of the numbers of patients in Tables 1 and 3 was adjusted in a small number of cases to be consistent with the National Cancer Institute (NCI) and SEER-Medicare guidelines. Although the data were not changed, their expression was amended. In addition, an acknowledgment of our gratitude to the NCI, SEER, the Office of Research, Development and Information of the Centers for Medicare \& Medicaid Services, and the Information Management Services, Inc. has been included.

The original article has been corrected.

The original article can be found online at https://doi. org/10.1007/s13555-020-00404-9.

S. Jang $(\bowtie)$

Melanoma and Cutaneous Oncology Therapeutics, Inova Schar Cancer Institute, Fairfax, VA, USA

e-mail: Sekwon.Jang@inova.org

T. Poretta $\cdot$ M. Burke $\cdot$ S. Rao

Health Economics and Outcomes Research, Bristol

Myers Squibb, Princeton, NJ, USA

T. Bhagnani · Q. Harshaw

Health Economics and Outcomes Research, EPI-Q

Inc., Oakbrook, IL, USA
Open Access. This article is licensed under a Creative Commons Attribution-NonCommercial 4.0 International License, which permits any non-commercial use, sharing, adaptation, distribution and reproduction in any medium or format, as long as you give appropriate credit to the original author(s) and the source, provide a link to the Creative Commons licence, and indicate if changes were made. The images or other third party material in this article are included in the article's Creative Commons licence, unless indicated otherwise in a credit line to the material. If material is not included in the article's Creative Commons licence and your intended use is not permitted by statutory regulation or exceeds the permitted use, you will need to obtain permission directly from the copyright holder. To view a copy of this licence, visit http://creativecommons.org/licenses/bync/4.0/. 